\title{
運動前の冷却刺激が中等度等尺性運動の継続時間に与える影響
}

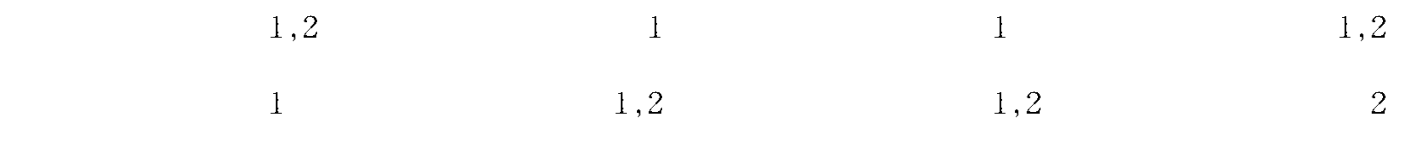

\section{INFLUENCE OF COOLING ON CONTINUANCE CONTINUOUS CONTRACTION TIME PRIOR TO MODERATE ISOMETRIC EXERCISE}

\author{
Masahiro Utsunomiya, Katsuyuki Morishita, Hiroshi Karasuno, Akihisa Yoshikawa, \\ KazUnori Morozumi, Kunio Yoshizaki, TAKayUki FujIWARA and KoJI ABE
}

\begin{abstract}
Purpose: To investigate the cooling effect on muscles prior to continuous isometric muscle contraction. Furthermore, tissue compliance, pressure pain threshold, deep tissue temperature, and tissue circulation volume were measured to investigate the cooling effect on a physical reaction. Method: The biceps brachii muscle was contracted isometrically and continuously at the $90(-)$ degree in flexion position with $40 \%$ of maximum contraction. The task was ceased when subjects could not keep over 70 degrees of elbow flexion. An injection type cooling stimulator was used on the biceps brachii muscle as a cooling modality. Results: The continuous contraction time in the cooled group increased significantly compared with the control group. In addition, tissue compliance and pressure pain threshold showed significant differences between the two groups. Conclusion: This study suggested that the isometric continuous contraction time in cooled muscles can be extended to $40 \%$ of MVC. The inhibition of muscle metabolism, an increase in the pressure pain threshold, and tissue compliance may affect muscle endurance.
\end{abstract}

(Jpn. J. Phys. Fitness Sports Med. 2009, 58:431 440)

key word : cold therapy, isometric continuous exercise, movement time, tissue compliance, pressure pain

$$
\text { I . 緒言 }
$$

現代の寒冷療法は, 1950年代初頭からスポーツ外 傷管理の手段としてアメリカで普及され，60年代後 半にアスレティックトレーナーによる積極的な使用 により広まったとされている．わが国におけるリハ ビリテーション分野での寒冷療法は, 1970年代の後 半に山内たち ${ }^{1)}$, 山内 ${ }^{2)}$ が極低温ガスの全身瀑射と 運動療法を組み合わせた，関節リウマチ患者に対す る治療効果を報告して以降関心が高まり, 多くの機 器も開発されてきた. 寒冷療法は, 身体の一部や全 身を冷却することで組織温の低下を引き起こし，こ れによる生理的反応を治療に用いる方法である . 冷 却による身体の生理的反応として局所の新陳代謝の
低下, 毛細管透過性の減少, 一次的血管収縮と二次 的血管拡張, 浅部疼痛受容器に対する閾值上昇作用, 筋紡鍾活動の低下などとされている3 ${ }^{3)}$. 適応として は，(1)外傷や筋·骨格系障害の急性期および外科的 手術後の局所の疼痛と筋スパズムの軽減，(2)外傷後 の炎症性侵出物質の抑制(炎症の活動期)，(3)関節疾 患や炎症による疼痛と筋スパズムの軽減,(4) 中枢神 経疾患の筋緊張の抑制,などが挙げられている ${ }^{4)}$.

冷却に関する先行研究において, Zemke et al. ${ }^{5)}$ は筋肉内温度変化を皮下注射針を改良したマイクロ プローブを用い測定し，アイスマッサージと水枕で の冷却効果の違いについて報告している．Bergersen et al. ${ }^{6)}$ は, 局所的冷却は動静脈吻合部の血管運動 神経の活動を引き起こし，冷却初期に血管狭窄が誘

\footnotetext{
1)学校法人こおりやま東都学園郡山健康科学専門学校 Koriyama Institute of Health Sciences

干963-8834 福島県郡山市図景2-9-3

2)信州大学大学院総合工学系研究科

干 386-8567 長野県上田市常田3-15-1 
発されることを報告している. Swenson et al. ${ }^{7)}$ は 寒冷療法を用いることはリハビリテーションプログ ラムの一部として回復時間を減少させるため有効で あるが 極低温における寒冷療法の長時間の使用は， 凍傷及び神経損傷のような重大な副作用を引き起こ す可能性があることを報告している．Wolf ${ }^{8)}$ は等 尺性最大筋収縮力は冷却により低下し, 冷却樣式と 冷却時間の長さに依存することを報告している．し かし，筋収縮時間に対する冷却の影響に関する報告 はあまり多くない，光のため筋収縮時間に対する効 果はいまだ不明確と考えられている．ただし，経験 則として身体の一部を冷却し筋パフォーマンスを低 下させないことに利用することは, スポーツ分野で よく見かける行為である . 例えばマラソン競技中の 下肢へ水をかける行為やサッカー競技中下肢を冷や す行為などである 筋活動量に対する冷却の影響を， Frank ${ }^{9)}$ は上肢の屈伸運動に対し最大負荷の $75 \%$ 負 荷量の運動を 1 セット 22 回とし，セット間で7.5分 間の休息を行い，休息中に 3 分間の冷却を行った冷 却群と対象群とで運動遂行不可となるまでのセット 回数と総運動量の比較実験を行った . 結果として総 仕事量では冷却を加えた群のほうが14.5\%増加する ことを報告し, 反復運動間の冷却は筋持久力を向上 させる可能性を示した . 冷却による筋活動への影響 を解明することができれば, 治療への応用も広がる 可能性があると考えた . 現在, 医療の現場では盛ん に「科学的根拠に基づいた医療」(Evidence Based Medicine）が論じられており，冷却が筋活動に与え る影響についての基礎データは必要であると考え
た. 光こで, 本研究では運動前の冷却が筋等尺性持 続的運動の継続可能時間に与える影響について調査 した . 運動前に10分間の安静を行う場合と, 運動前 10分間の冷却を試行した場合とで，元の後の運動継 続時間を計測し比較した .また，どのような生理的 反応が影響しているか検討するため, 圧痛閾値・組 織硬度・組織循環量・深部組織温度を計測し検討し た。

$$
\text { II. 対象 }
$$

本研究は事前に学校法人こおりやま東都学園研究 倫理委員会の承認を受けた . 対象者は上肢に機能障 害および循環障害のない健常成人男性 9 名とした。 対象者には本研究の趣旨を口頭と書面にて説明し同 意を得た . 対象者の年齡は平均 $28.6 \pm 4.2$ 歳, 身長 は $173.2 \pm 6.4 \mathrm{~cm}$ ，体重は $65.0 \pm 8.2 \mathrm{~kg}$ であった . 対 象者の身体的特徵は, International Society for the Advancement of Kinanthropometry 基準（以下 ISAK基準) に準じ，Level 2 の資格を持つ計測技師 が行った ${ }^{10)}$. 対象者の身体的特徵として, 上腕前 面 (Biceps folds) の皮脂厚 (Skin folds) は右2.5 $\pm 1.1 \mathrm{~mm}$, 周経 (Girths) は肘関節屈曲位上腕弛緩 周経 (Arm relaxed) で右 $27.4 \pm 2.0 \mathrm{~cm}$, 肘関節屈 曲位上腕緊張周経 (Arm flexed and tensed) で右 $29.9 \pm 2.0 \mathrm{~cm}$ ，であった (Table 1$)$.

$$
\text { III. 方法 }
$$

対象者には 1 週間前より，翌日まで筋肉痛の継続 するような過度の運動を行わないよう指示した．ま

Table 1. Physical characteristics of subjects.

\begin{tabular}{c|c}
\hline Number of subject & 9 \\
\hline Age $(\mathrm{yrs})$ & $28.6 \pm 4.2$ \\
\hline Height( $\mathrm{cm})$ & $173.2 \pm 6.4$ \\
\hline Weight $(\mathrm{kg})$ & $65.0 \pm 8.2$ \\
\hline Biceps folds $(\mathrm{mm})$ & $2.5 \pm 1.1$ \\
\hline Arm relaxed $(\mathrm{cm})$ & $27.4 \pm 2.0$ \\
\hline Arm flexed and tensed $(\mathrm{cm})$ & $29.9 \pm 2.0$ \\
\hline $100 \%$ MVC $(\mathrm{kg})$ & $18.1 \pm 4.0$ \\
\hline $40 \% M V C(\mathrm{~kg})$ & $7.2 \pm 1.6$ \\
\hline
\end{tabular}

Values are means $\pm \mathrm{SD}$. 
た計測開始の 4 時間前より禁煙とし，さらに2 時間 前より飲食を禁止とした . 実験室の環境は室温24一 $26^{\circ} \mathrm{C}$ ，相対湿度 $40 \sim 60 \%$ とし可及的に一定とした . 対象者の服装は上衣半乥でのシャツとした .

運動前の処置は, (1)安静10分間 (以下,コントロー ル群)，(2)10分間の冷却 (以下, 冷却群) の2 群と した . 各試行の順番はランダムとし, 対象者の筋疲 労が影響しないよう，1 週間以上の日数を空け行っ た. 9 名の対象者に対して安静と冷却の 2 試行を実 施した。

冷却には, 噴射型冷却刺激装置 (Cryo 5：伊藤 超短波社製）を用いた．送風レベル 3 , 対象部位と 噴出口の距離は約 $15 \mathrm{~cm}$ にて上腕中央前面を中心と し移動法で熟練したセラピストが施行した . 冷気の 温度は噴出口温度 $-20^{\circ} \mathrm{C}$, 皮膚表面冷気平均温度 5 足であった .

対象者の処置中の肢位は, ベッド上に仰臥位とな り肩関節 90 度外転位, 内外旋中間位, 屈曲伸展中間 位, 肘関節軽度屈曲位, 手関節中間位, 手指は力を 抜いた自然な肢位とした (Fig.1).また，測定中は
可能な限り安静を保つように指示した .

運動課題は，仰臥位にて肩関節外転90度，肘関節 90 度屈曲位で, 対象者の前腕に直角に負荷がかかる よう調節したハンドグリップを握り，关の位置を保 ち続ける等尺性持続運動とした . 運動課題に対する 負荷は, 同姿勢にて肘関節最大屈曲筋力を竹井社製 アナログ式握力計にて測定し，弚の $40 \%$ (40\%MVC) とし，重錘にて負荷を加えた．重錘の微調整は 1 個 $5 \mathrm{~g}$ の鉄球を用い行った . 運動終了は肘関節の屈曲 角度が70度以上を保持できなくなった時点とした。 組織循環量の測定には, 近赤外線分光器（ニロモ ニタNIRO-200：浜松ホトニクス社製）を用いた。 測定のプローブは右上腕外側部 (上腕二頭筋長頭筋 腹中央外側) の皮膚上に貼付固定した . 総へモグロ ビン(以下 Total-Hb)を組織循環量の指標とした .

深部組織温度の測定は, 深部温度計 (コアテンプ CM-210：TERUMO 社製)を使用した 測定のプロー ブは右上腕内側部に貼付固定した . 2 つの測定装置 のプローブを装着後30分間の環境順化を行い各数値 が安定したことを確認し測定を開始した . 測定時間

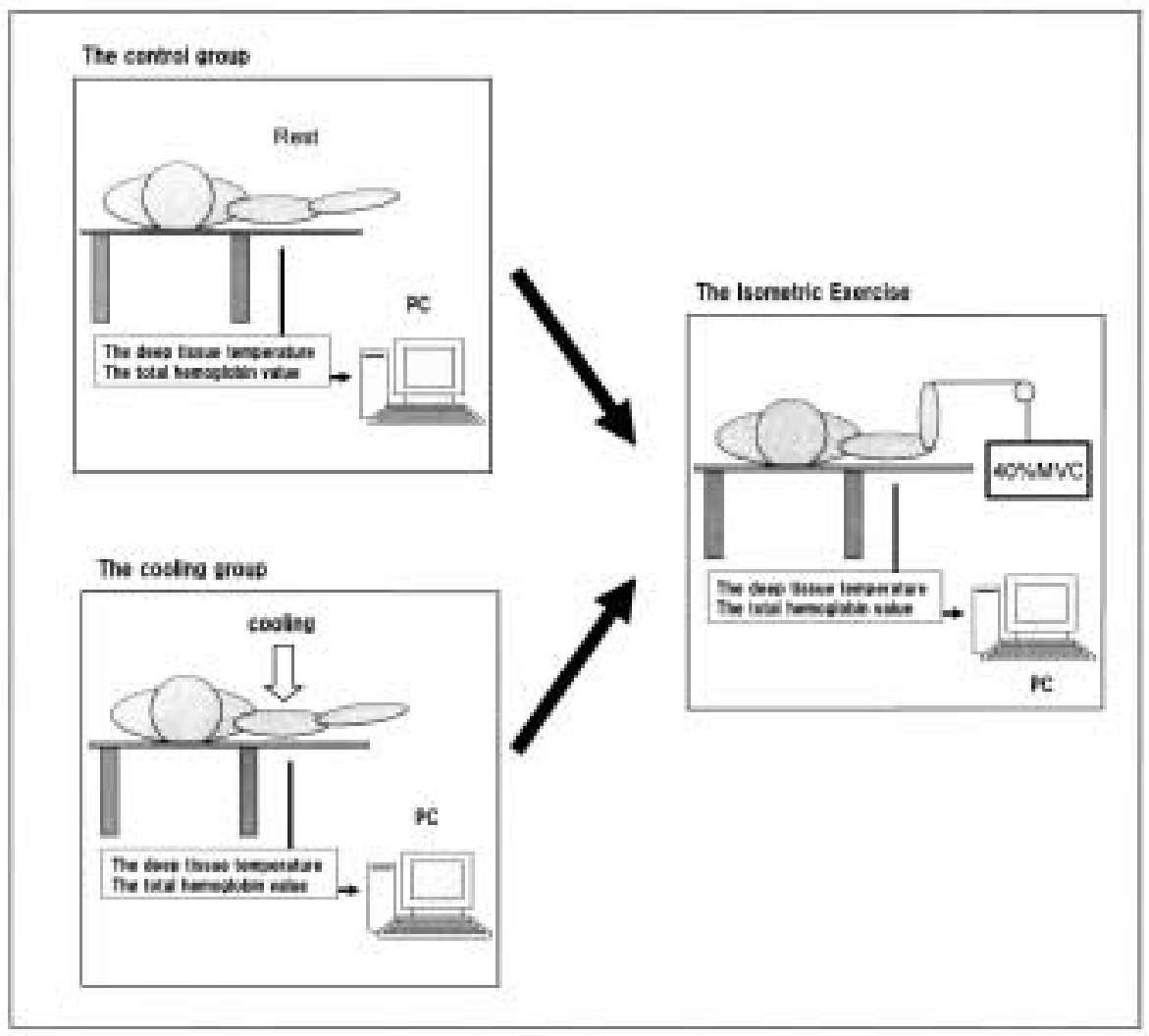

Figure 1. Block diagram

MVC: Maximum Voluntary Contraction

$\mathrm{PC}$ : Personal computer 
は処置前 2 分間 (T1), 処置中 (安静, 冷却) 10 分 間 (T2)，運動負荷中 (T3)，運動終了後10分間 (T4) とした .

痛覚閾値の測定は, 圧痛計 (Accelerated Care Plus社製プロトタイプ) を用いた . 軟部組織硬度 の測定は, 軟部組織硬度計 (Accelerated Care Plus 社製プロトタイプ $)^{11)}$ を用いた . 2つの測定は, T1 直前 (測定開始前)，T2 直後 (処置後)，T4 終了時 (測定終了後) の計 3 回実施し, 測定部位は上腕中 央部とした．各測定は 3 試行平均值を代表值とした .

(Fig.1・Fig.2)

\section{N. データ処理と統計処理}

A . 運動継続時間は, コントロール群と冷却群の 2 群間で比較した ささらに, 各対象者のコントロー ル時の運動継続時間を用い正規化を行った．

B . 組織硬度および圧痛閾值は, 測定開始前, 処置 後, 測定終了後を同群間と 2 群間で比較した .

C. 深部組織温度と組織循環量は, T1の平均值を 基準値とし, T2・T4について 1 分間毎の平均
值を算出，T3については各対象者の運動継続 時間に違いがあるため, 運動継続時間を 3 分割 し初期 (T3-E)，中期 (T3-M), 終期 (T3-L) の平均値を算出し基準值で正規化し比較した． 統計学的処理はSPSS 11.5J for Windowsにて 2 元配置分散分析を用い危険率 $5 \%$ 末満を有意とし た.

$$
\text { V. 結果 }
$$

\section{A. 運動継続時間（Fig.3)}

Fig. 3 に両群の運動継続時間を示した . 運動継続 時間は, コントロール群196.7 \pm 105.6 秒 $(100 \%)$ ， 冷却群 $230.3 \pm 105.6$ 秒 $(123.0 \pm 21 \%)$ と冷却群に おいて有意な時間延長を示した $(\mathrm{P}<0.01)$.

\section{B. 圧痛閾值 ( Fig.4)}

Fig.4 に両群の圧痛閾值を示した .コントロール 群は，測定開始前 $15.8 \pm 3.8 \mathrm{~N}$, 処置後 $17.8 \pm 3.5 \mathrm{~N}$, 測定終了後 $17.4 \pm 3.0 \mathrm{~N}$ であった．冷却群は，測定 開始前 $17.7 \pm 5.2 \mathrm{~N}$, 処置後 $24.2 \pm 5.3 \mathrm{~N}$, 測定終了

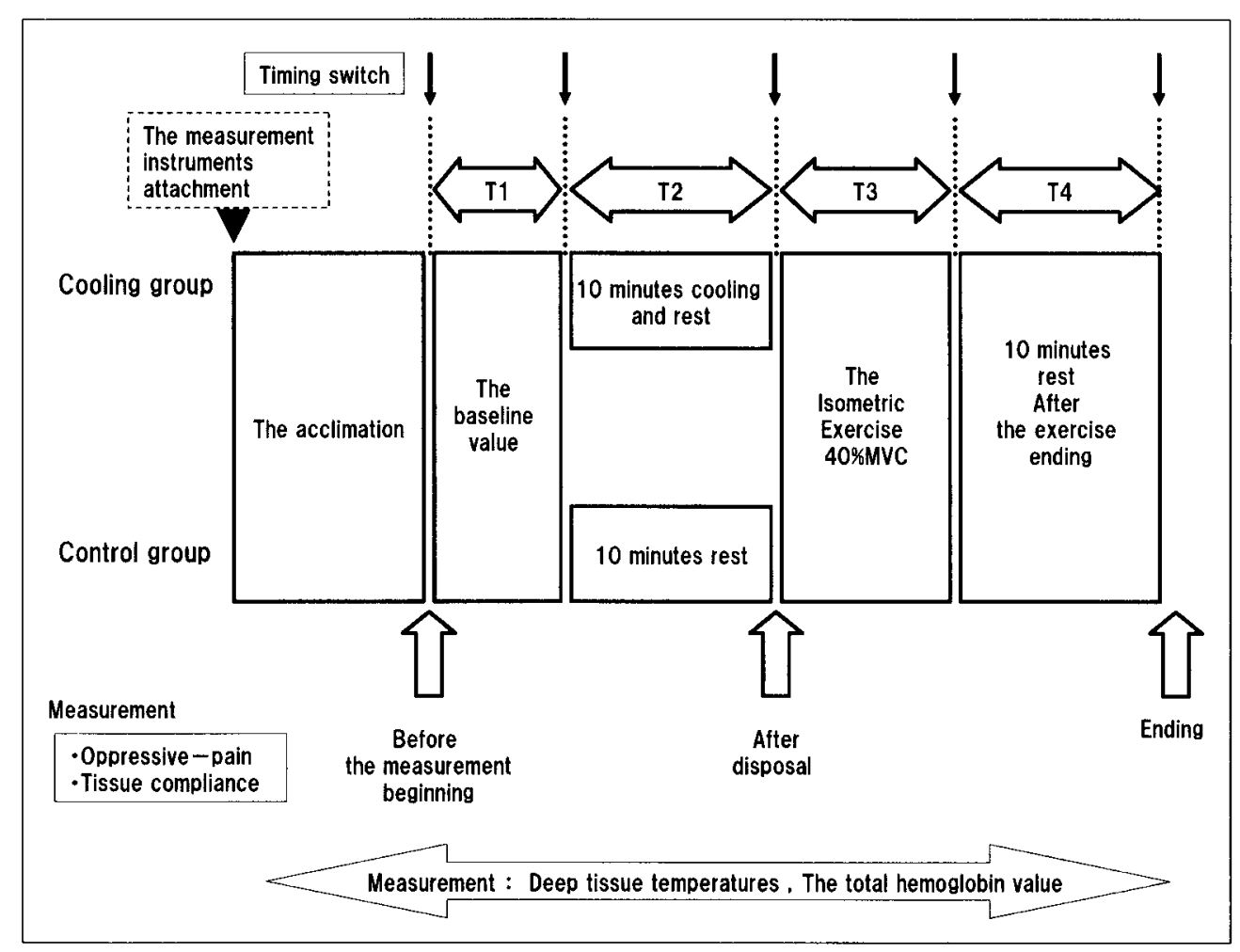

Figure 2. Protocol

T1 was baseline values which were average during the initial 2 minutes. The phase T2 was 10 minutes for cooling group and control group. The T3 was the continuous muscle contraction phase which was divided among three phases. T4 was after the exercise. 


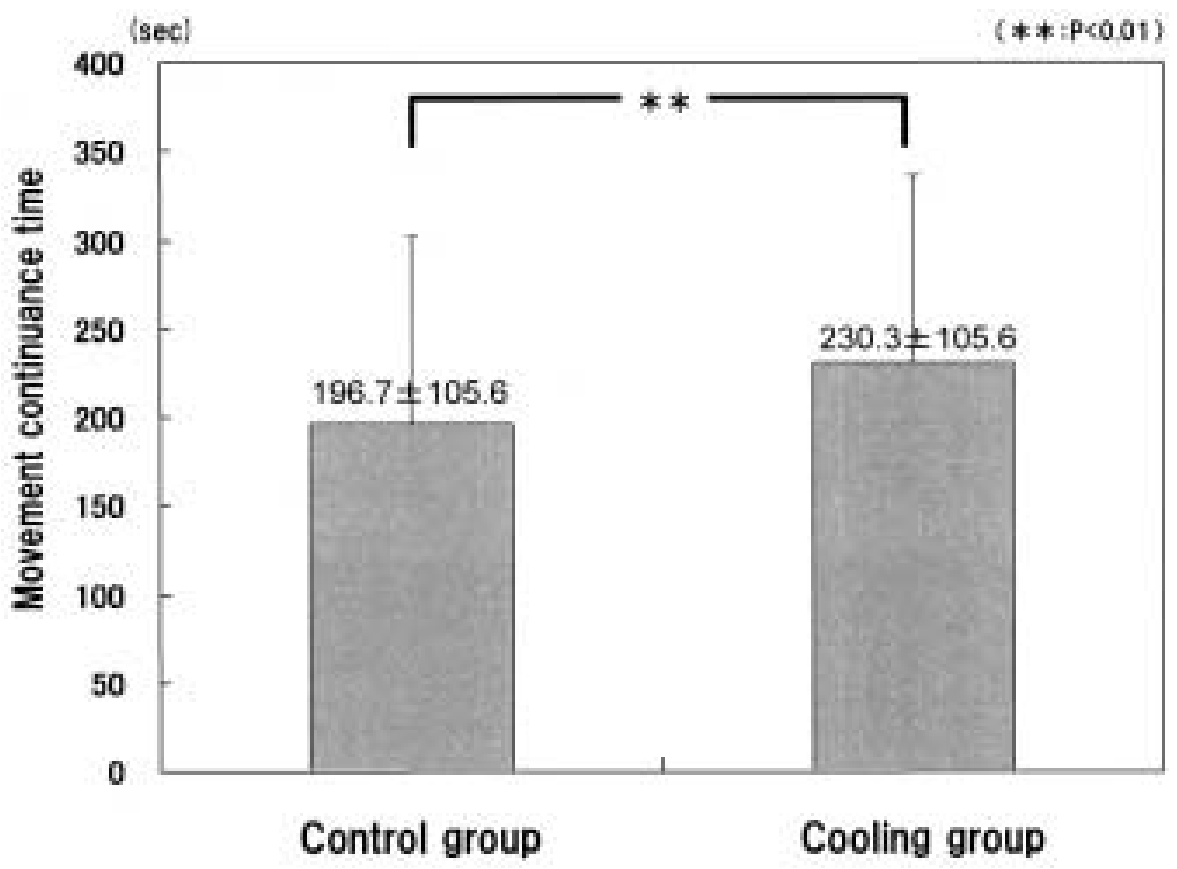

Figure 3. Movement continuance time Values are mean $\pm \mathrm{SD}$.

* * Statistically different $(\mathrm{P}<0.01)$ from control.

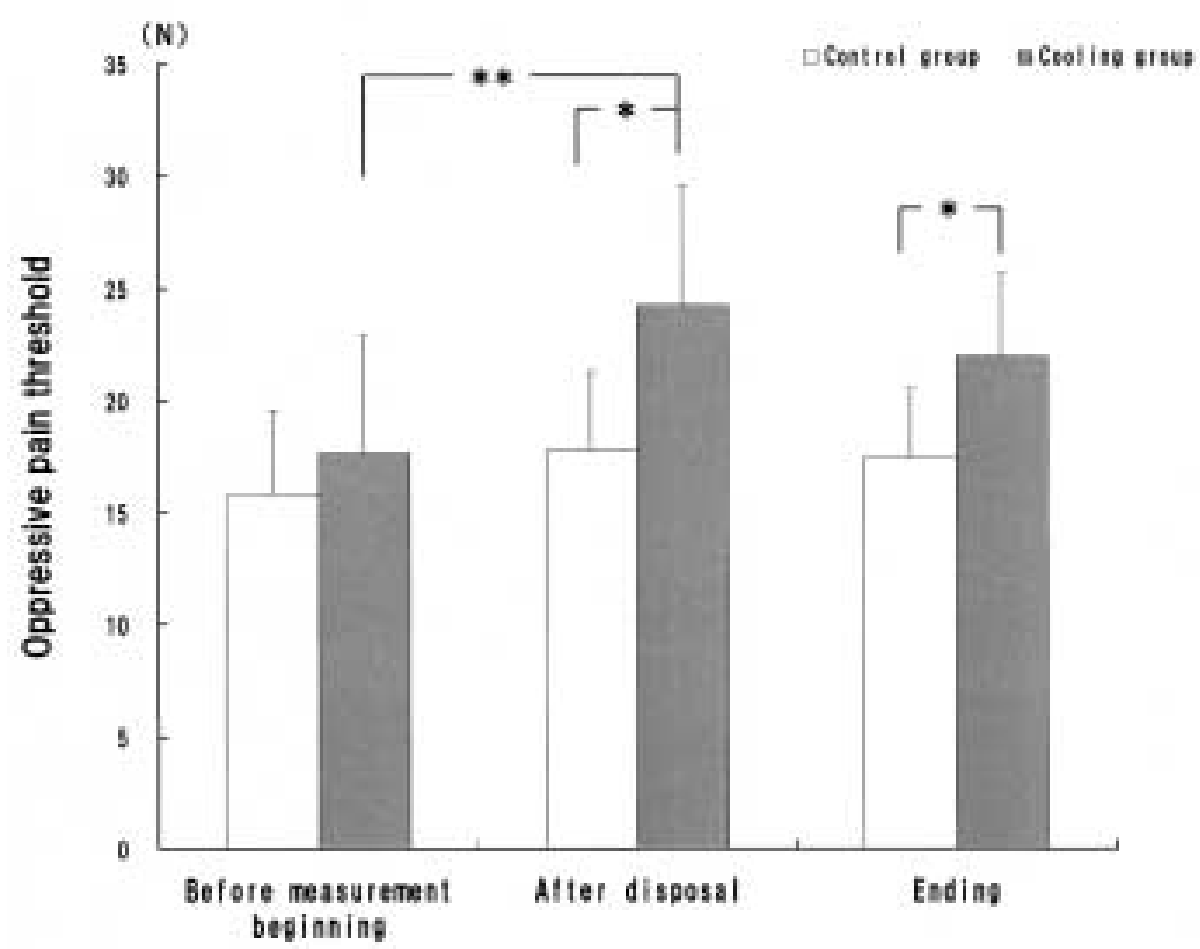

Figure 4. Oppressive pain threshold.

Values are mean $\pm \mathrm{SD}$.

$* *$ Statistically different $(\mathrm{P}<0.01)$ from cooling group.

* Statistically different $(\mathrm{P}<0.05)$ from control. 
後 $22.0 \pm 3.6 \mathrm{~N}$ であった . 冷却処置の前, 冷却処置 後の運動前, 運動後の 3 回の測定においてコント ロール群では圧痛閾值の有意差は認められなかった が，冷却群では測定開始前より処置後が有意に大き い值となった $(\mathrm{P}<0.01)$. また, コントロール群 と冷却群の比較では処置後と測定終了後に冷却群が 有意に大きな值となった $(\mathrm{P}<0.05)$.

\section{C. 組織硬度 ( Fig.5)}

Fig. 5 に両群の組織硬度を示した.コントロール 群は, 測定開始前 $58.1 \pm 3.9 \%$, 処置後 $54.6 \pm 3.1 \%$ ，

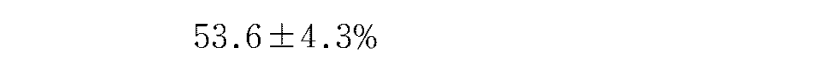
開始前 $57.2 \pm 3.7 \%$, 処置後 $64.2 \pm 6.7 \%$, 測定終了 後 $55.2 \pm 5.6 \%$ であった . 冷却処置の前, 冷却処置 後の運動前, 運動後の 3 回の測定においてコント ロール群では有意差は認められなかったが, 冷却群 では測定開始前より処置後が有意に大きな值となっ た $(\mathrm{P}<0.01)$. また, コントロール群と冷却群の 比較では処置後に冷却群が有意に大きな値となった $(\mathrm{P}<0.01)$.
D. 深部組織温度 (Fig.6• Fig.7)

Fig.6にコントロール群のサンプルデータを示し た.Fig.7に両群の深部温度を正規化したものを示 した .コントロール群では T2 の大きな変動は認め られず，T3-Eより上昇を始め終了時まで上昇傾 向が認められた . T4-4 以降において T1より有意 に大きい值となった $(\mathrm{P}<0.05)$. 冷却群では, T2 -5より T4-6間において T1より有意に小さな值と なった $(P<0.05)$. また, 測定終了時まで上昇傾 向であったが基準值までの回復は認められなかっ た.コントロール群と冷却群の比較では $\mathrm{T} 2-5$ 以 降終了時まで冷却群が有意に小さな值となった ( $<0.05)$.

\section{E. 組織循環量( Fig.8・Fig.9)}

Fig.8に冷却群のサンプルデータを示した . Fig. 9 に両群の総へモグロビン相対值を平均したものを示 した .コントロール群では, 安静中では変動が見ら れず，持続的運動中の T3-Eから T3-L 間は，T1 および T4-1から $\mathrm{T} 4-4$ 間より有意に小さな值と なった $(\mathrm{P}<0.05)$. 持続的運動終了後より急激に

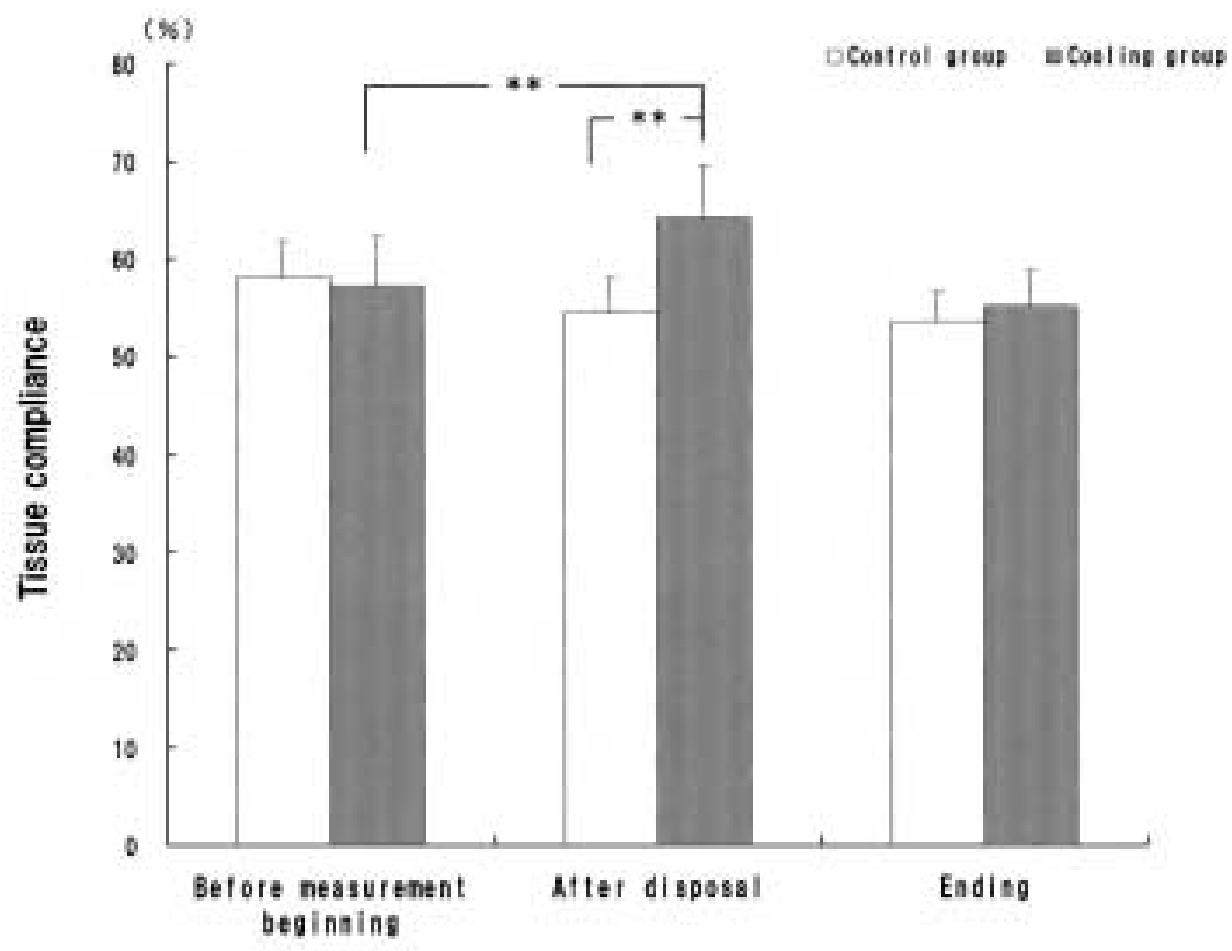

Figure 5. Tissue compliance.

Values are mean $\pm \mathrm{SD}$.

$* *$ Statistically different $(\mathrm{P}<0.01)$ from cooling group. 
( $\mathrm{C}$ )

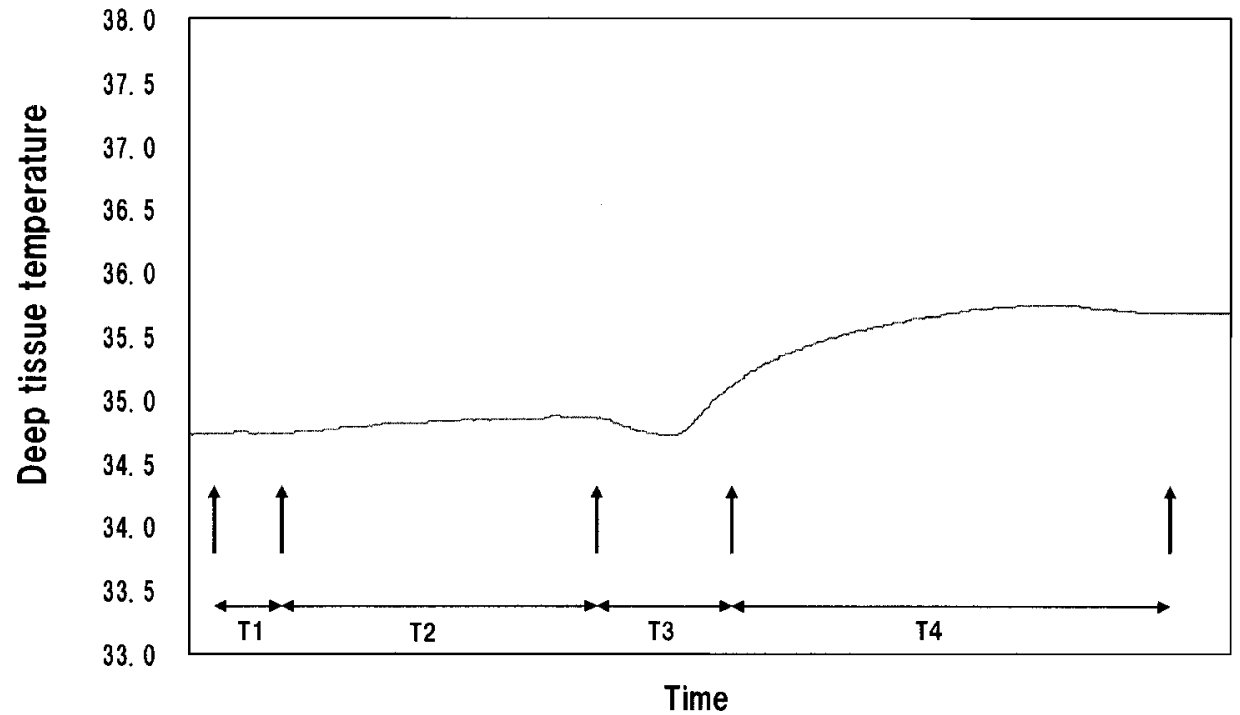

Figure 6. Raw data of deep tissue temperature

The phase $\mathrm{T} 1$ was baseline values which were average during the initial 2 minutes. The phase $\mathrm{T} 2$ was 10 minutes treatment. The phase T3 was the continuous muscle contraction. The phase T4 was after the exercise.

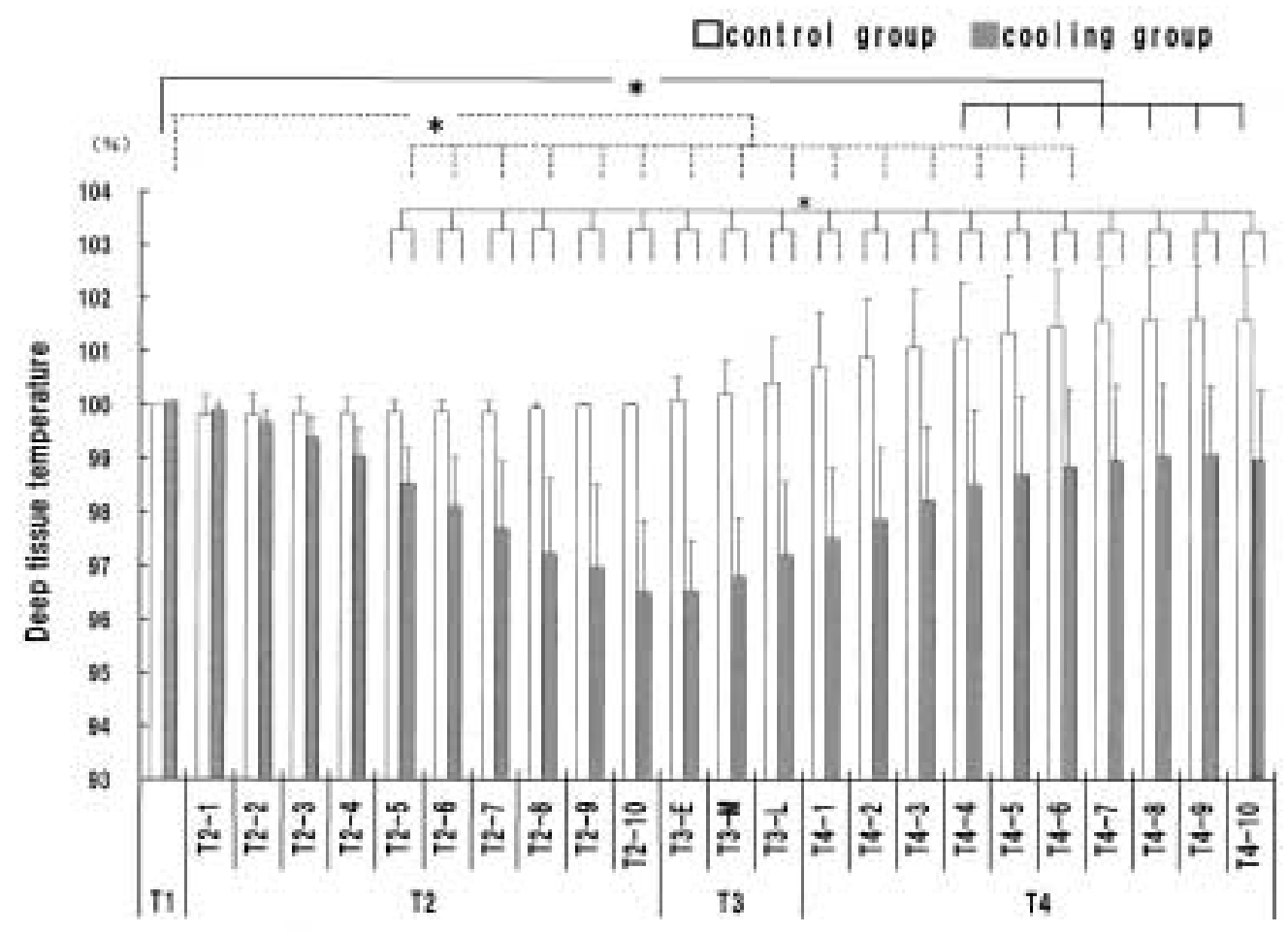

Figure 7. Deep tissue temperature of the upper arm.

Values were mean \pm SD. $\quad *$ Statistically different $(P<0.05)$.

There are four period ( T1 to T4). T1 was baseline values which were average during the initial 2 minutes. The Phase T2 was 10 minutes for cooling group and control group. The T3 was the continuous muscle contraction phase which was divided among three phases (T3-E:early, T3-M:middle and T3-L:last). T4 was after the exercise. Each value was average value for 1 minute. Phase T2 to T4 was divided baseline value of T1. 


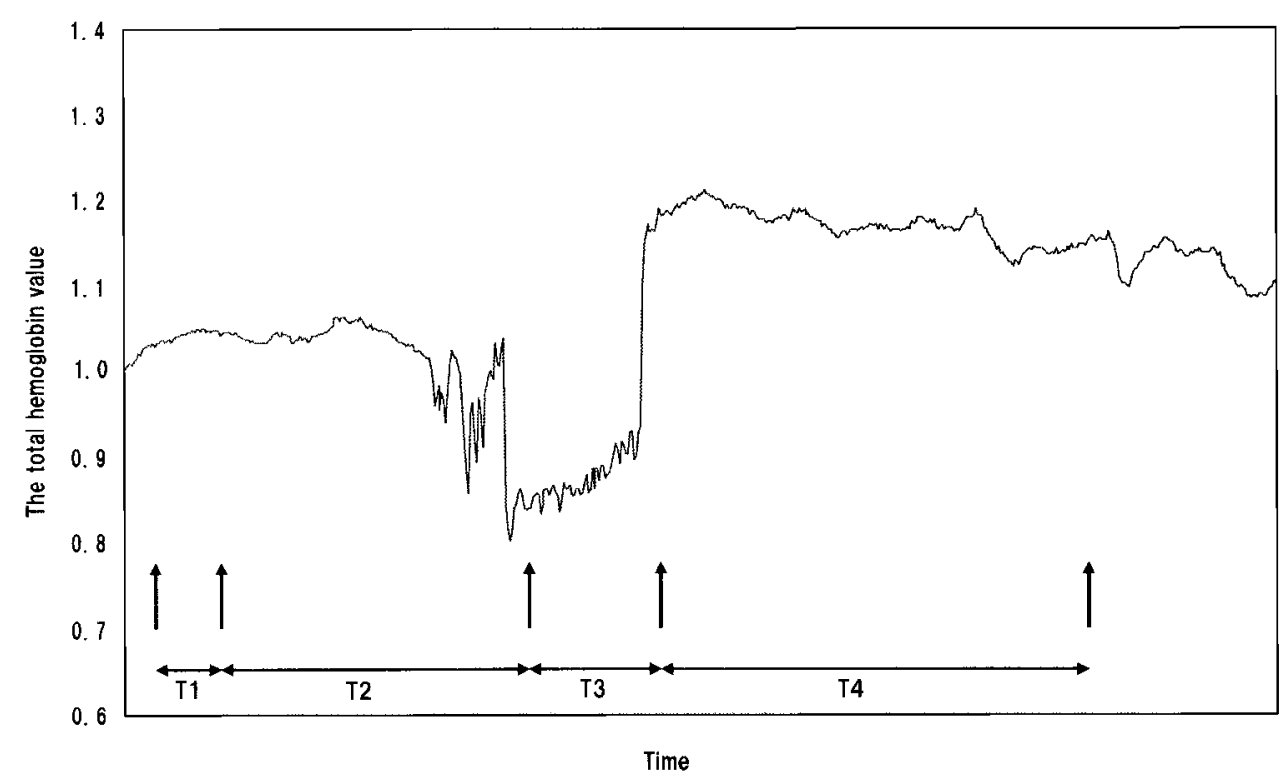

Figure 8. Raw data of total hemoglobin value

The phase $\mathrm{T} 1$ was baseline values which were average during the initial 2 minutes. The phase T2 was 10 minutes treatment. The phase T3 was the continuous muscle contraction phase. The phase T4 was after the exercise.

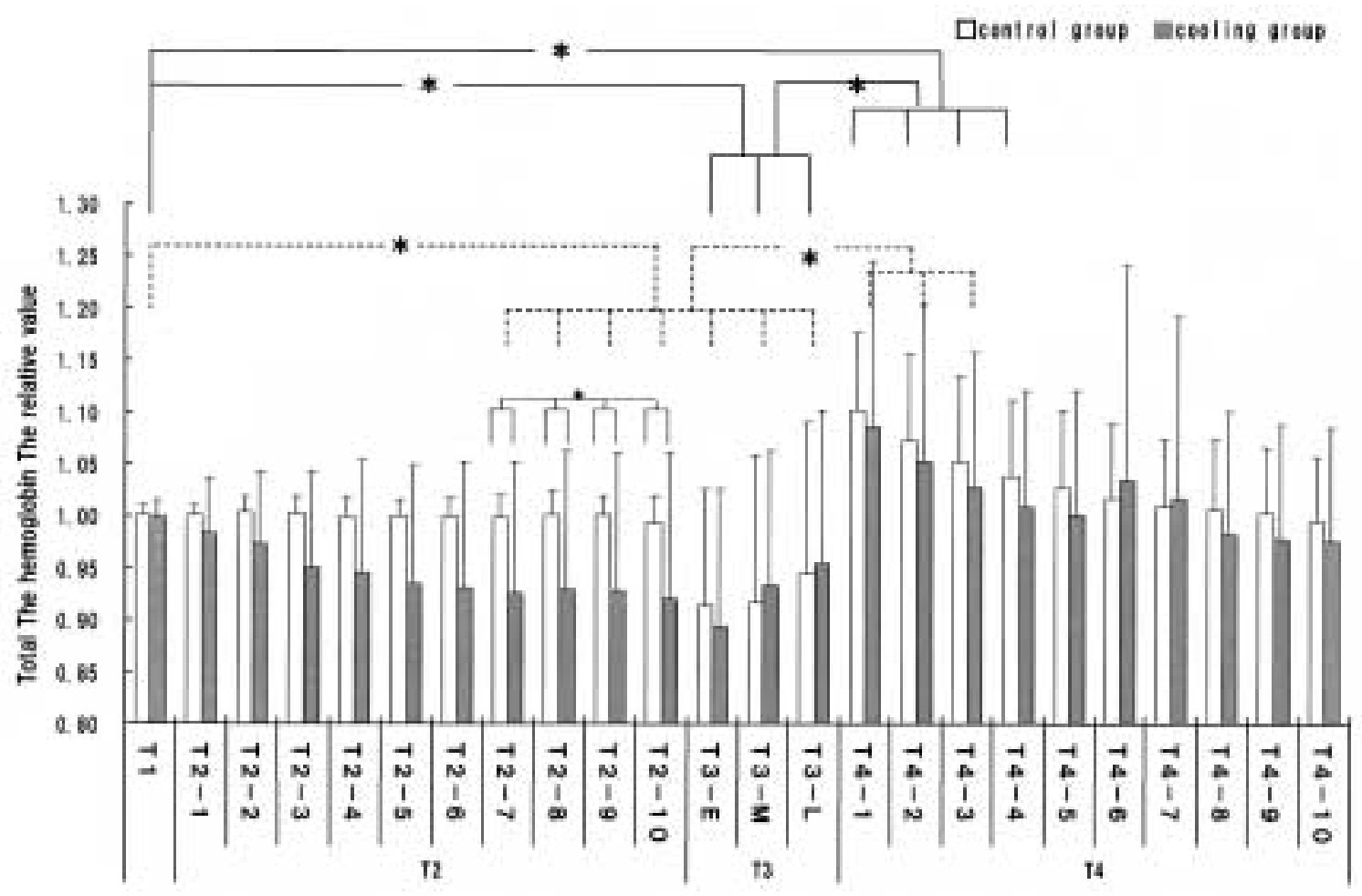

Figure 9. The total hemoglobin value.

Values were mean \pm SD. * Statistically different $(\mathrm{P}<0.05)$.

There are four period ( $\mathrm{T} 1$ to T4). T1 was baseline values which were average during the initial 2 minutes. The Phase T2 was 10 minutes for cooling group and control group. The $\mathrm{T} 3$ was the continuous muscle contraction phase which was divided among three phases (T3-E:early, T3-M:middle and T3-L:last). T4 was after the exercise. Each value was average value for 1 minute. Phase T2 to T4 was divided baseline value of T1. 
増加し終了時まで徐々に基準値に回復する傾向を示 した . T4ー1から T4-2間は T1より有意に大きな 值となった $(\mathrm{P}<0.05)$. 冷却群では, 冷却中低下 し続け持続的運動時には, さらに低下を示した。 T2-7から T3-L間は, T1および T4-1から T43 間より有意に小さな値となった $(\mathrm{P}<0.05)$. 持続 的運動終了後急激に増加し終了時まで徐々に基準値 に回復する傾向を示した .コントロール群と冷却群 の比較では $\mathrm{T} 2-7$ から $\mathrm{T} 2-10$ 間で冷却群が有意に 小さな値となった $(\mathrm{P}<0.05)$.

\section{U. 考察}

本研究の目的は, 運動前の冷却刺激が運動継続時 間に与える影響を検討すること，またどのような生 理的反応が起こるかを観察することである．

本研究では等尺性運動を課題としたが, Hunter et al. ${ }^{12)} ら に よ る と$ 冷却により関節運動時の抵抗が 増し, 冷却部の関節運動スピードが低下したと報告 している．今回は筋活動継続時間に主眼をおいてい るため，関節運動を伴わない等尺性運動を選択した . また, 先行研究の多くは四肢末梢を測定部位として いる．しかし，臨床に活用できる部位を測定するこ とで応用範囲が広がると考え, 上腕部を測定部位と した．皮脂厚は冷却効果に影響を与えるため測定を 行った . 測定は国際基準として使用されている ISAK 基準に準じて行った . 測定結果より上腕部の 皮脂厚は薄く標準偏差も小さいことより実施部位と しては適当であると考えられる．

また，本研究では冷却による生理的反応の指標と して組織循環量, 深部組織温度, 圧痛閾值, 筋硬度 を利用した . 組織循環量は, Jöbsis \& Rosenthal ${ }^{13)}$ によって，へモグロビン酸素化および酸化還元状態 を吸収スペクトル変化として観察できる近赤外線分 光法を用いた . 冷却による血行動態やエネルギー代 謝を無侵襲で連続測定でき広く活用されている方法 である . 深部組織温度は組織内の冷却程度の確認を リアルタイムに行えるコアテンプを使用した . 貼付 部位を筋腹中央にすることで直下の筋温度を反映で きるものと考える . 筋硬度は先行研究においてあま り報告のないものであるが，筋の収縮には活動張力 と静止張力の関与があり, 組織硬度の変化は静止張 力の変化を反映すると考えた . 圧痛閾值は冷却によ る疼痛の軽減は認められるものの未だ客観的な指標
は少ない新しい試みとして用いた .

研究の結果より, 冷却群において運動継続時間は 有意な増加を示した . コントロール群 $100 \%$ とする と，冷却群では $123 \%$ であり，約 $20 \%$ の運動継続時 間の延長が認められた . 持続的運動前に筋を冷却す ることで $40 \% \mathrm{MVC}$ の負荷での等尺性運動継続時間 は延長することが示された . Halar et al. ${ }^{14)}$ は冷却 適用中に正中神経の知覚神経の経皮的伝導速度が低 下することを報告した . 今回の実験において冷却群 の処置後に圧痛閾値の有意な低下が確認されてい る.これは冷却による組織温度の低下に伴い神経組 織も温度低下を起こし, 圧痛閾値の増加が引き起こ されたと考えられる．光れにより筋疲労感を軽減で きたのではないかと考えた.さらに ,Clarke et al. ${ }^{15)}$ らは前腕部で機械的な筋のスティッフネスが温度低 下により筋線維の粘性上昇により高まることを報告 している，本実験結果においても，冷却後の組織硬 度は上昇していることが確認されている. 軟部組織 の粘弾性が上昇し静止張力を引き上げ持続的な運動 に有利に働いたと考えられる.運動継続時間の延長 の要因として，圧痛閾值の上昇や組織硬度の上昇も 関与しているのではないかと考えられる .

また, 深部組織温度の変化は冷却後約 3 分程度の 時間的経過か認められる. 外部からの冷却による温 度低下には組織を伝播するために一定の時間が必要 とされる結果と考えられる. 先行研究において， Bierman \& Friedlander ${ }^{16)}$ は深部組織の温度低下 は冷却後数分間認められないことを確認し, 深部組 織までの到達時間の遅れを報告している．Lowden \& Moore ${ }^{17)}$ は冷却部の深部組織の温度低下は, 光 の部位の皮下脂肪組織の量に関係していることを報 告している. 今回の実験の冷却部位は上腕中央前面 であり, 対象者の皮脂厚も $2.5 \pm 1.1 \mathrm{~mm}$ と比較的薄い 場所であったため， 3 分程度で泠却効果か現れたと 考えられた . また, 深部組織温度の上昇は運動開始 後より両群で確認されている．筋活動による熱産生 は基礎代謝時に約 $20 \%$ を占め, 活動時には午の数倍 になることが報告されている．運動後の深部組織温 度の上昇は筋活動による活発な熱産生の結果である と考えられる. Blair ${ }^{18)}$ は, 冷却により温度低下を 引き起こされた細胞の代謝活動は低下し, 細胞での 酸素消費やエネルギー必要量は低下することを報告 している．本研究においても深部組織温度低下によ 
り同等の活動時の酸素消費やエネルギー必要量が低 下したことが推測され，これも運動時間の継続に有 利に働いたと考えられた .ただし，人体は部位や性 別また体型により皮脂厚に大きな差がある．治療で 用いる場合には皮下組織の違いを測定し，伝導時間 も考慮する必要があると考えられる．

最後に, 組織循環量は深部組織温度の変化と関連 が強く，組織温度の低下に伴い循環量の低下が認め られた · また，両群において運動中の循環量の低下 が認められたが，これは筋収縮により筋内圧が高ま り動静脈血管を圧迫した物理的作用であると考えら れる. 運動後の急激な組織循環量の上昇が引き起こ されることは血管に対する圧力が除去された結果で ある . 炎の後の循環量の増加は酸素負債を補うため と, 筋緊張による交感神経の活動性上昇によるもの と推測される.組織循環量は深部組織温度と筋活動 の影響を強く受けることが示された .

今回の研究において運動継続時間の延長に影響は 認められたが, 温熱との比較研究等, 今後さらに研 究を継続し寒冷による筋活動への影響を検討する必 要があると思われる .

$$
\text { VII . 結語 }
$$

$40 \% \mathrm{MVC}$ の負荷量で肘関節 $90^{\circ}$ での等尺性運動 継続時間をコントロール群と冷却群にて比較した . 谷の結果, 冷却群において運動継続時間は有意に延 長し, 運動前の冷却は中等度の等尺性運動に対して は効果的であることが示唆された . 乥れは深部組織 温度の低下により，組織硬度が上昇し筋粘弾性の増 加が引き起こされたこと, 冷却による同程度の運動 に対するエネルギー消費量の抑制が引き起こされた ことが運動時間の延長に有利に働いたのではないか と推察された .

(受理日 平成21年 6 月 2 日)

\section{引用文 献}

1) 山内寿馬, 野上貞夫，延永 正，慢性関節リウマチ に対する局所冷凍マッサージの効果, リ八医学, (1977)，14，47-55.

2) 山内寿馬, 極低温療法の応用と運動療法一慢性関節
リウマチを中心として一，理・作療法 , (1981) , 15， 497-501 .

3) 大森豊明, 生体物理刺激と生体反応, 初版, 温熱の リハビリテーション医療への応用, (跈フジ・テクノ システム , 東京 , (2004)，556-565。

4) 松澤正, 物理療法学, 金原出版株式会社, 東京, (2008), 50-71.

5) Zemke J. E., Andersen J. C., Guion W. K., McMillan J., \& Joyner A. B., Intramuscular temperature responses in the human leg to two forms of cryotherapy: ice massage and ice bag. J. Orthop. Sports Phys. Ther. (1998), 27, 301-307.

6) Bergersen T. K., Hisdal J., \& Walløe L., Perfusion of the human finger during cold-induced vasodilatation. Am. J. Physiol.,(1999), 276, 731-737.

7) Swenson C., Swärd L., \& Karlsson J., Cryotherapy in sports medicine.Scand. J. Med. Sci. Sports, (1996), 6 , 193-200.

8) Wolf S. L., Contralateral upper extremity cooling from a specific cold stimulus. Phys. Ther.,(1971), 51, 158-165.

9) Frank M., Interval cryotherapy decreases fatigue during repeated weight lifting. J. Athl. Train.,(2000), 35 , $422-426$.

10) 香川雅春, ISAK講習会 Level2 テキスト, 特定非営 利活動法人健康科学研究センター, (東京), 2004.

11) Morozumi, K, Fujiwara, T, Karasuno, H, Castel F. C., Palermo X., \& Draper D. O., Reliability of tissue compliance meter and algometer. 13th International Pain Clinic Congress, (2008), 27-30.

12) Hunter J., Kerr E. H., \& Whillans M. G .,The relationship between joint stiffness upon exposure to cold and the characteristics synovial fluid. Can. J. Med. Sci., (1952), 30, 367-377.

13) Jöbsis F. F., \& Rosenthal M., Cerebral energy consumption and provision: the predominance of neuronal oxidative metabolic processes. Ciba. Found. Symp.,(1978), 56, 129-148.

14) Halar E. M., DeLisa J. A., \& Soine T. L., Nerve conduction studies in upper extremities: skin temperature corrections. Arch. Phys. Med. Rehabil.,(1983), 64, 412-416.

15) Clarke R. S. J., Hellon R. F., \& Lind A. R., Vascular reactions of the human forearm to cold. Clin. Sci.,( 1958), 17, 165-179.

16) Bier man W., \& Friedlander M., The penetrative effect of cold. Arch. Phys. Ther., (1940), 21, 585-592.

17) Lowden B. J., \& Moore R. J., Determinants and nature of intramuscular temperature changes during cold therapy. Am. J. Phys. Med., (1975), 54, 223-233.

18) Blair E., Clinical hypothermia. McGraw-Hill, New York, (1964), 22-30. 